\title{
Interaction Design of Refreshable Braille Display to Support Learning for the Visually Impaired Kids
}

\author{
Anisa A. Muttaqina, Andhika Estiyono, and Ari D. Krisbianto \\ Departemen Desain Produk, Fakultas Arsitektur Desain dan Perencanaan, \\ Institut Teknologi Sepuluh Nopember (ITS) \\ e-mail: andhika@prodes.its.ac.id
}

\begin{abstract}
Impaired vision is a condition where someone is unable to see clearly, even when they are using glasses and in condition where there is enough amount of light. Impaired vision in Indonesia is not only become health problem, but has already become social problem. One of the social needs is education. However, people with impaired vision have differences way in how they learn, because they use braille characters in their education process. There is a device to support the braille learning which name is refreshable braille display. However, the devices are usually sold in a very expensive price. Based on the background and the above phenomenon, this research is about to do the design of low-cost refreshable braille display for educational needs.
\end{abstract}

Keywords-Impaired Vision, Education, Braille Display.

\section{INTRODUCTION}

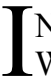
NDONESIA has $3.05 \%$ citizens with impaired vision [1]. With the number above $0.5 \%$, impaired vision in Indonesia is not only become health problem, but has already become social problem [1]. One of the needs of an individual is the need for education.

The need for education can be fulfilled by attending formal education in school or non-formal education. However, people with impaired vision have differences way of learning because they use braille characters instead of alphabetical characters. A research has been done by EduBraille team to obtain lowcost technology for supporting the braille-based learning that is able to compete with existing refreshable braille display.

However, the device they designed does not have a suitable user interface for the potential user and the device has not provided good feedback. Therefore, it is proposed research on the design of enclosures on refreshable braille display devices developed by EduBraille. The method used in this research is a deep interview, observing, user persona, and user testing.

\section{RESEARCH METHOD}

\section{A. Reverse Engineering}

Reverse engineering is used in this research to get to know about the existing low-cost refreshable braille display material, layout, and its component.

\section{B. Workflow Analysis}

Workflow analysis is used in this research to get a data about how the product works and how is the work flow of the product. The method is using a basic logical pattern.

\section{Structure of Interaction Analysis}

Interaction structure analysis is used in this research after
Table 1

Reverse Engineering

\begin{tabular}{ll}
\hline Figure & \multicolumn{1}{c}{ Explanation } \\
\hline & $\begin{array}{l}\text { In the form of temporary outer packaging, } \\
\text { there are screens for braille cells, buttons } \\
\text { for accessing products, ports for power and } \\
\text { cable jacks, and holes for speakers and } \\
\text { ventilation. Casing part is divided into 2, }\end{array}$
\end{tabular}

namely upper part and lower part.

Appearance of speaker hole in product packaging. The dimensions of each hole are $(3 \times 15) \mathrm{mm}$

The appearance of the left side of the product, consists of the power on / off button to activate the product and port for the product power cable. The power button uses a push button type.

Appearance of the right side of the product. Consisting of volume adjusters, ports for audio jacks, and ventilation holes. The dimensions of the ventilation hole are the same as the dimensions of the speaker hole.

Appearance of the bottom of the product. There are bolts of size $2 \times 5 \mathrm{~mm}$ and $2 \times$ $10 \mathrm{~mm}$ for joining casing of the bottom and top.

Appearance of the contents of the electronic component configuration on the product. Consisting of mechanical components drive braille, button, audio, $\mathrm{CPU}$, and speaker.

\section{Result:}

In this reverse engineering, the results are in the form of several fragile and sensitive component properties such as the mechanical components of braille cells. In the process of working, the braille mechanical components also experience an increase in temperature. So, taking into account the safety of the equipment, material that is not easily damaged, must be resistant to collisions and must consider the possibility of a high temperature increase so that it must use material that has a high melting point or heat resist. 
the researcher get the workflow analysis. Interaction structure analysis itself has a purpose to get to know the number of each structure in the interaction process.

\section{User Testing}

User testing is carried out by carrying out product trials directly to the user. This method is carried out by creating a scenario where the respondent as a prospective user will be given a task in accordance with the product to be tested to get a final design which will then be made a prototype.

\section{RESULT AND DISCUSSION}

\section{A. Reverse Engineering}

The following table is a reverse engineering carried out on refreshable braille display products by EduBraille. The image in Table 1 is a temporary packaging that has been made.

\section{B. Workflow Analysis}

Product workflow studies are needed to determine the flow of product usage and be used as a reference in arranging the layout of product interfaces.

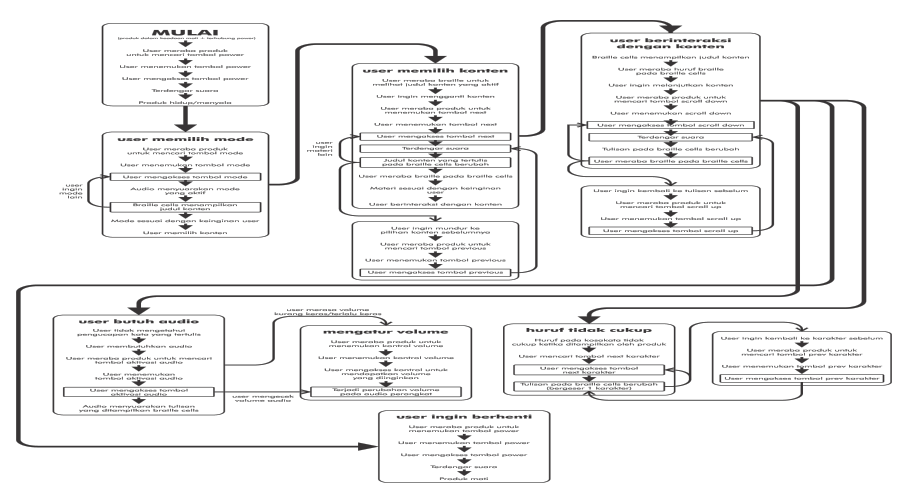

In the flow of product operation, the first time a user search is a trigger to turn the product on or off.

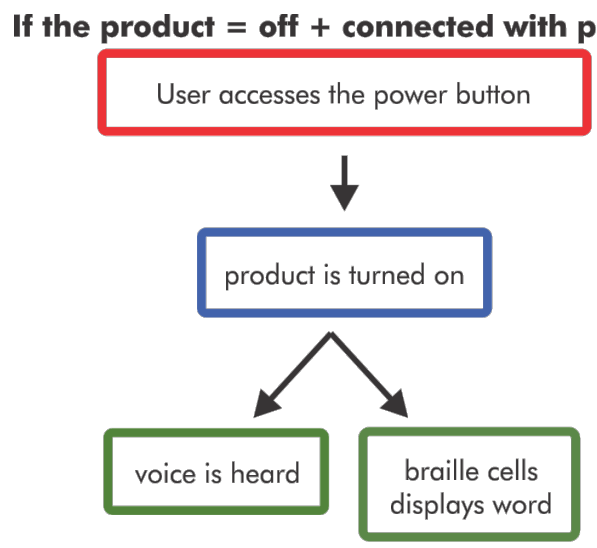

If the product $=$ on

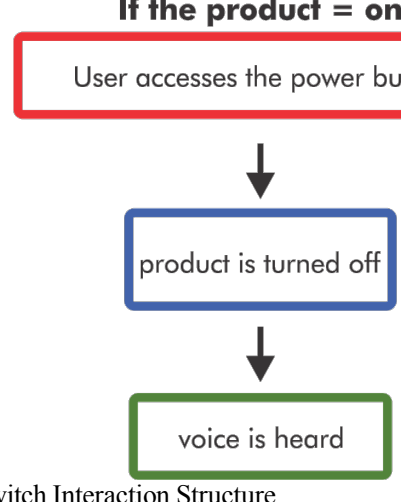

Figure 2. Power Switch Interaction Structure.

\section{Mode button}

After turning on the product, the user selects the learning model available on the product. A looping occurs in the user's actions in interacting with modes.

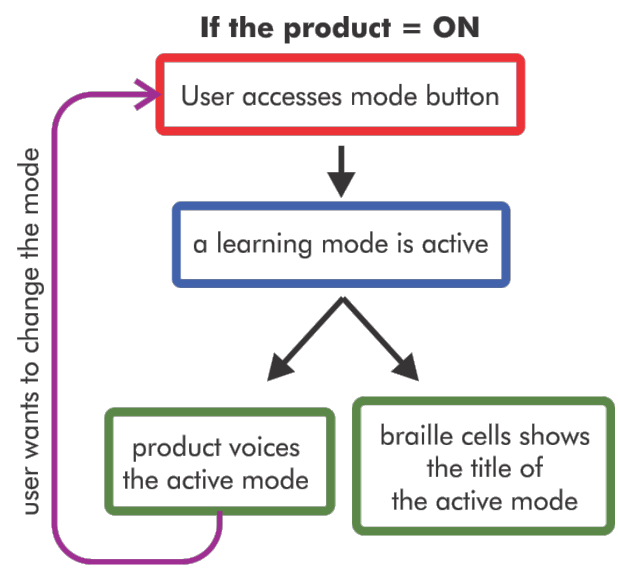

Figure 3. Mode Interaction Structure.

\section{Next/Back Content}

After selecting the mode, the user selects the content available in that mode.
Figure 1. Workflow Analysis.

\section{Interaction Structure Analysis}

1. Power switch 


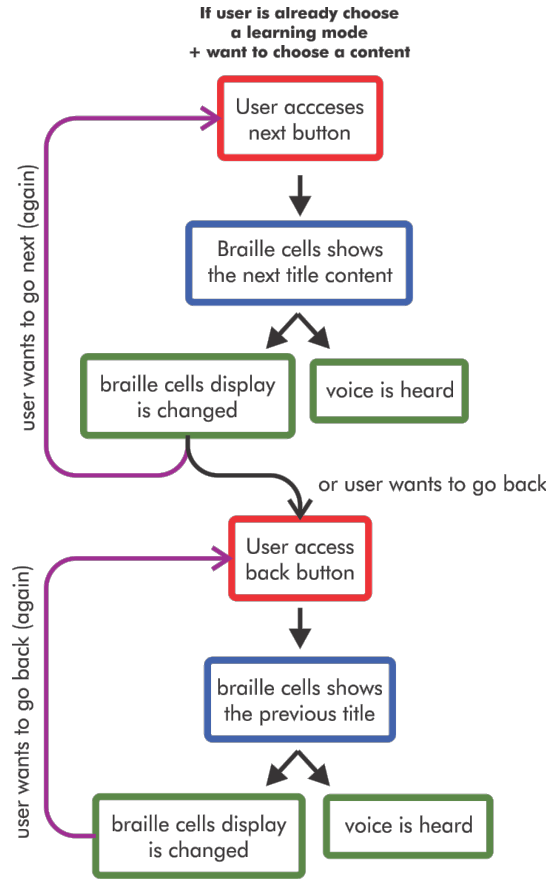

Figure 4. Next/Back Content Interaction Structure.

\section{Scroll Up/Down}

When the user has entered into the content provided by the product, the interaction that occurs is that the user reads the content and requires a trigger to continue or return to the previous article. Then the user will interact with the scroll up and down button.

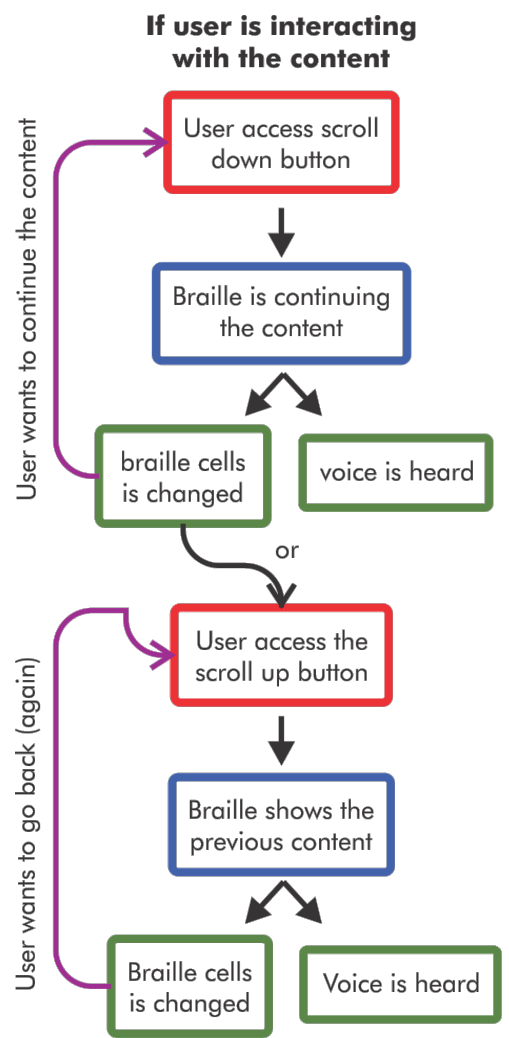

Figure 5. Scroll Up/Down Interaction Structure.

5. Next/Prev Character
When the display of words on braille cells is not enough, the user needs an interaction to shift the braille cells display so that they can see the continued cut off, so the user will interact with the next and previous character buttons.

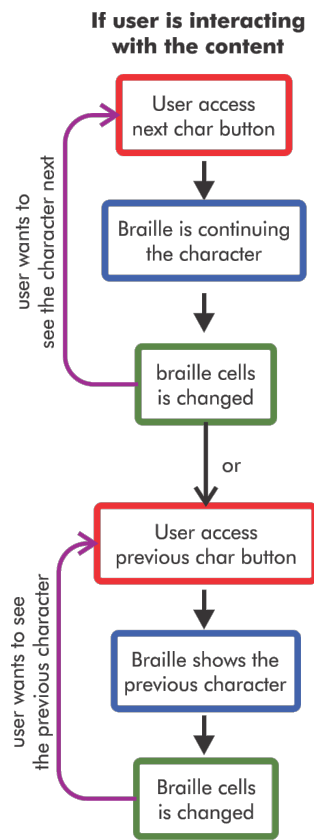

Figure 6. Next/Prev Character Interaction Structure.

\section{Audio dan Volume}

Users access the audio activation button when they want to know how to read the posts that are being touched on braille cells. Users can also adjust the volume released by the product by accessing the volume adjuster.

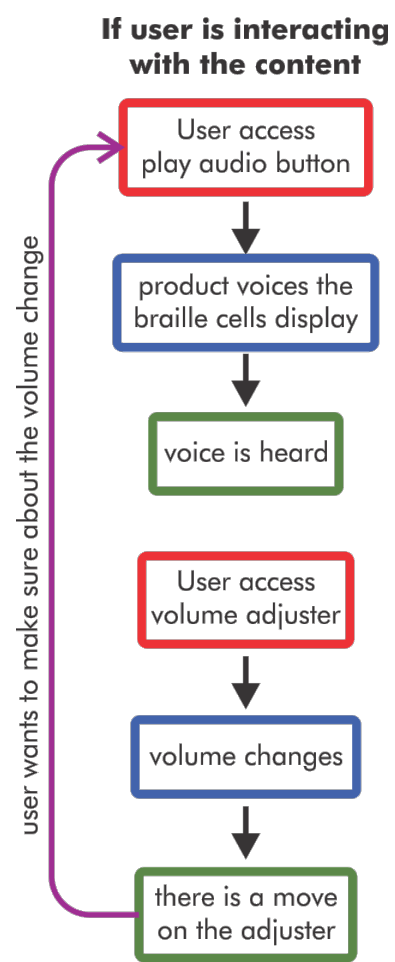

Figure 7. Play Audio and Volume Adjuster Interaction Structure.

So that it can be concluded from the analysis of the structure of this interaction that: 
a. The product has 10 triggers which consist of; power switch, mode, next content, back content, scroll up, scroll down, next character, previous character, audio activation, and volume adjuster.

b. Obtain menu and sub-menu divisions represented by buttons:

1. Menu: Mode button

2. Sub-menu: Next and Back content buttons

\section{User Testing}

In user testing experiment, researcher used 3 different layouts of interface and some audio-effects to find the most suitable audio feedback for the product. The interface layout uses the principle of designing a user interaction and based on the workflow of the product. The audio-effects used in the testing is based on user interests.

Table 2

User Testing Data Collection

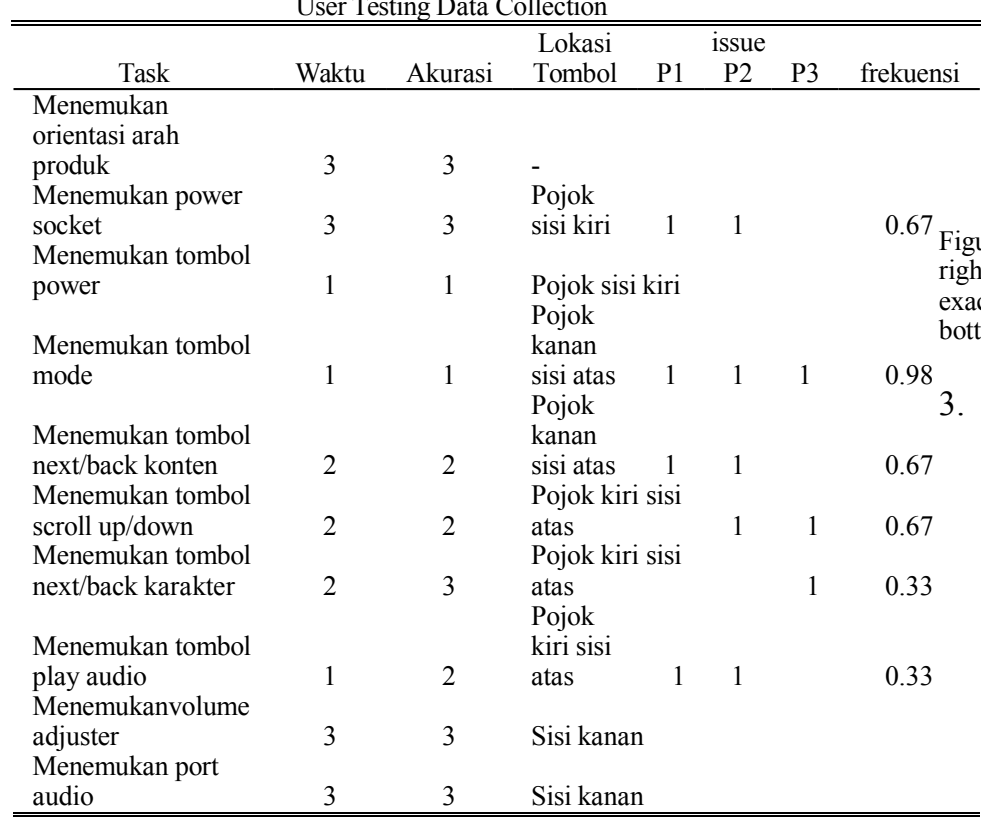

In the table above, the timing and accuracy of the button search are indicators in assessing the frequency of the severity of the product. The greater the number (3), the task requested in the product is more easily understood by respondents. While the smaller the number (1), the respondents experienced problems in time and accuracy.

After conducting the usability test on the existing product, a solution is provided for the stages that are experiencing difficulties. Usability solutions are also measured according to the available indicators.

The usability test is using these 3 different layouts for finding the alternative design.

1. Layout 1

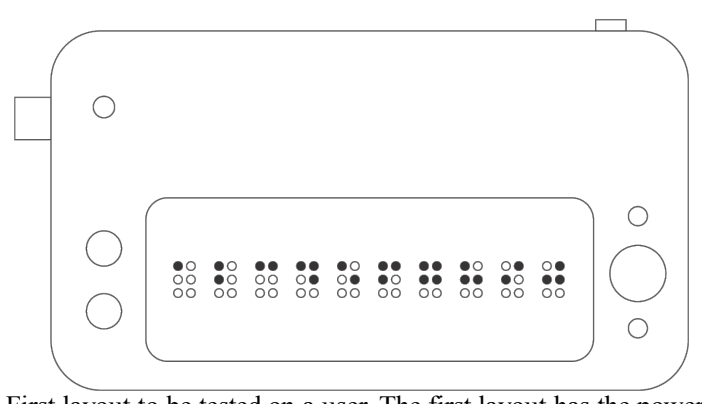

Figure 8. First layout to be tested on a user. The first layout has the power menu on the upside of the product, and then the mode button has a bigger size than the content button. The play audio has the smallest size of the button. Volume adjuster is placed on the left side of the product.

\section{Layout 2}

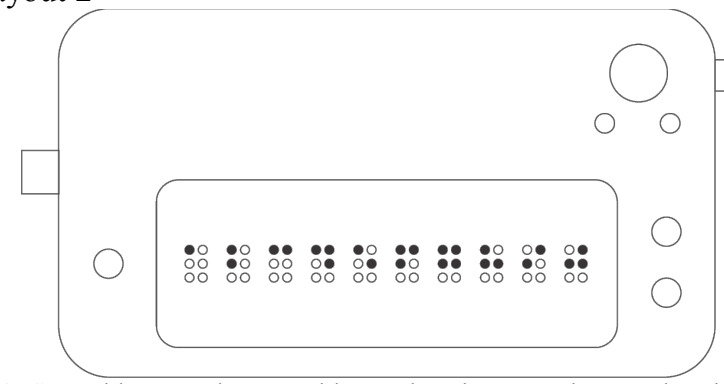

. Second layout. The second layout has the power button placed on the right side of the product. The mode button is placed in the front of the product exactly after accessing the power button. The content button is placed right in the bottom of mode button. Volume adjuster is still placed in the left of the product.

3. Layout 3

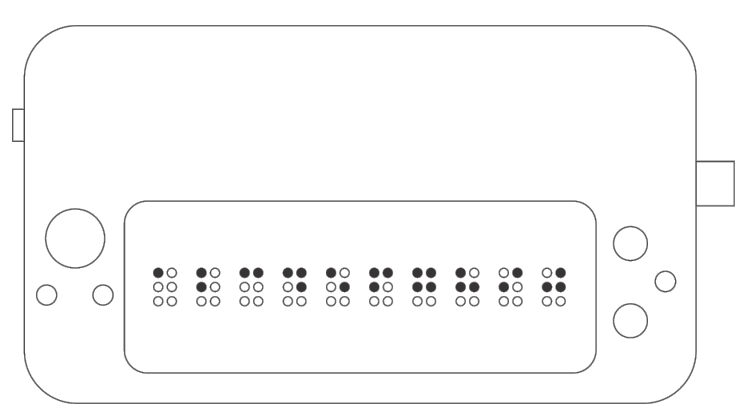

Figure 10. Third layout. The third layout has the power button on the left side of the product. The mode button has the bigger size than the content button. The scroll up and down button is placed on the right in the front side of the product. The audio button is place besides the scroll button. The volume adjuster is placed in the right side of the product.

In the solution generalization and its priorities table, it is shown that problem solving has been done with a solution based on the usability research collection data table. The solution is measured according to the time indicator and product accuracy, so that when the respondent makes a mistake, the issue respondent column is marked with a number 1. After usability tests on the solution, the effectiveness of the solution to the problem is calculated based on the number of respondents. After getting the highest level of effectiveness, the solution is used as an alternative to the design.

Table 3

Solution generalization $\&$ its priorities

\begin{tabular}{|c|c|c|c|c|c|}
\hline & & & $\begin{array}{l}\text { Issue } \\
\text { Responden }\end{array}$ & & \\
\hline Solusi & Waktu & Akurasi & I1 $\mathrm{I} 2$ & I3 & Efektivitas \\
\hline $\begin{array}{l}\text { Memindahkan } \\
\text { tombol power ke }\end{array}$ & 3 & 3 & & & 1 \\
\hline
\end{tabular}




\begin{tabular}{|c|c|c|c|c|c|c|}
\hline \\
\hline \multicolumn{7}{|l|}{$\begin{array}{l}\text { kanan } \\
\text { Memindahkan } \\
\text { tombol power ke }\end{array}$} \\
\hline $\begin{array}{l}\text { belakang } \\
\text { Memindahkan } \\
\text { tombol mode di }\end{array}$ & 1 & 2 & & 1 & 1 & 0.5 \\
\hline $\begin{array}{l}\text { kanan dengan } \\
\text { power di kanan }\end{array}$ & 3 & 3 & & & & 2 \\
\hline $\begin{array}{l}\text { Memindahkan } \\
\text { tombol mode di } \\
\text { kiri dengan power }\end{array}$ & & & & & & \\
\hline & \multicolumn{5}{|c|}{$\begin{array}{l}\text { Menghilangkan } \\
\text { tombol next/back }\end{array}$} & 0.75 \\
\hline konten saja & 3 & 3 & & & & 1 \\
\hline $\begin{array}{l}\text { Memindahkan } \\
\text { tombol scroll } \\
\text { down/up ke sisi }\end{array}$ & & & & & & \\
\hline depan & 2 & 3 & & & 1 & 0.75 \\
\hline \multicolumn{5}{|l|}{ Mengganti volume } & & \\
\hline ke slide & 3 & 3 & & & & 1 \\
\hline \multicolumn{7}{|l|}{$\begin{array}{l}\text { Mengubah layout } \\
\text { next konten ke atas }\end{array}$} \\
\hline konten ke atas kiri & 1 & 2 & 1 & & & 0.75 \\
\hline \multicolumn{7}{|l|}{$\begin{array}{l}\text { Memindah tombol } \\
\text { mode ke pojok }\end{array}$} \\
\hline kanan sisi atas & 1 & 1 & 1 & 1 & 1 & 0.25 \\
\hline $\begin{array}{l}\text { Memindahkan } \\
\text { layput scroll down }\end{array}$ & & & & & & \\
\hline kanan & 2 & 3 & & & 1 & 0.75 \\
\hline
\end{tabular}

E.

Design Offered

Here is the offered design for refreshable braille display products. In this design, the product enclosure part is made separate from the enclosure of braille cells mechanical components, so that in the maintenance process technicians only remove part enclosures attached to mechanical braille cells. The arrangement of button layouts is adjusted to the position of the index and middle fingers when operating the product. The next and previous character buttons are placed on the front side so that they increase the size of the width of the product. For the braille cell section, the display is raised by 1 millimeter.

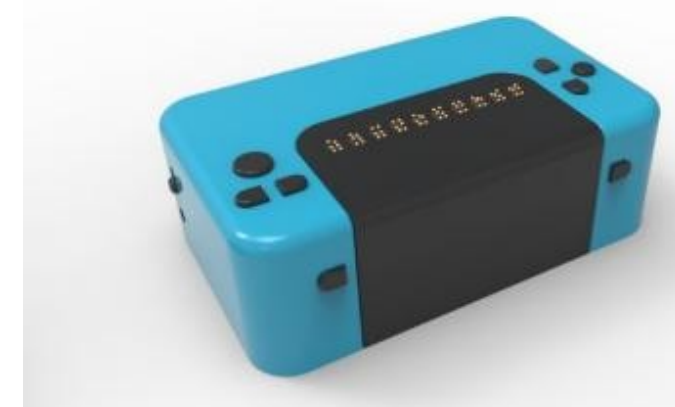

Figure 11. Design Offered.

\section{CONCLUSION}

In user testing experiment, researcher used 3 different layouts of interface to find the most suitable audio feedback for the product. The interface layout uses the principle of designing a user interaction and based on the workflow of the product. The audio-effects used in the testing is based on user interests.

\section{REFERENCES}

[1] Kementerian Kesehatan RI, "Situasi gangguan penglihatan dan kebutaan,” Jakarta, 2014. 